EDUKACJA MIĘDZYKULTUROWA

2012, nr 1

ISSN 2299-4106

\author{
Anna MŁynarczuk-SokoŁowska, \\ KATARZYNA SzOSTAK-KróL
}

\title{
Bajki międzykulturowe - w poszukiwaniu rozwiązań metodycznych w obszarze edukacji międzykulturowej dzieci w wieku przedszkolnym i wczesnoszkolnym
}

Streszczenie: Artykuł charakteryzuje możliwość realizacji edukacji międzykulturowej wśród dzieci w wieku przedszkolnym i wczesnoszkolnym poprzez wielokulturowe opowieści na przykładzie Programu Rozwoju Wrażliwości na Inność „Przygody Innego". Podstawę tego programu stanowi seria lekcji prowadzonych zgodnie $\mathrm{z}$ następującym porządkiem: lekcje z zastosowaniem opowieści międzykulturowych wzbogacone o aktywizujące metody nauczania, a następnie lekcje utrwalające, których celem jest konsolidacja wiedzy z poprzednich lekcji i rozszerzenie jej o nowe elementy z nią związane. Opowieści międzykulturowe mieszczą się zarówno w kanonie opowiadań psycho-edukacyjnych, jak i w nurcie edukacyjnej (rozwojowej) biblioterapii. Praca z omawianymi opowieściami umożliwia kształtowanie wrażliwości na inność $\mathrm{w}$ różnych aspektach (biologicznym, ekonomicznym, społecznym i kulturowym). Umożliwia także studentom kontakt z różnorodnością świata, nadanie jej wartości oraz rozwinięcie ciekawości kognitywnej oraz chęci interakcji z Obcym/Innym. Opowieści międzykulturowe stwarzają przestrzeń dla przygotowania dziecka na kontakty z Obcym/Innym poprzez pogłębione refleksje czytelników, rewaluację sposobu patrzenia na różnicę, są one także przydatne w pracy nad zachowaniem. Ponadto, oddziałują na proces rozwoju tożsamości dziecka poprzez tłumaczenie jego własnej przynależności do specyficznej (narodowej, etnicznej, religijnej) grupy i wartości, które reprezentuje.

Słowa kluczowe: edukacja międzykulturowa, bajki międzykulturowe, dzieci $\mathrm{w}$ wieku przedszkolnym i wczesnoszkolnym.

\section{Wprowadzenie}

Spotkania z Obcym/Innym bliskim i dalekim stają się naturalnym elementem współczesnej rzeczywistości społeczno-kulturowej. W dużej mierze to od edu- 
kacji zależy, jaki kształt będą one przyjmować. Edukacja jest czynnikiem umożliwiającym nadawanie wartości odmienności, przechodzenia od postrzegania innych ludzi w kategoriach zagrażających Obcych do inspirujących Innych oraz przeciwdziałania rozwojowi zjawiska dyskryminacji, które jest wpisane w funkcjonowanie społeczeństw wielokulturowych. W kontekście powyższego znaczenia nabiera przygotowywanie do kontaktów z Obcymi/Innymi już od najmłodszych lat oraz poszukiwanie atrakcyjnych i efektywnych sposobów realizacji edukacji międzykulturowej. Wiek przedszkolny i wczesnoszkolny jest okresem szczególnie ważnym z perspektywy uwrażliwiania na odmienność, która umożliwia partnerskie egzystowanie w warunkach różnic międzyludzkich i międzykulturowych, gdyż w tym czasie zaczynają kształtować się między innymi negatywne stereotypy i uprzedzenia dotyczące różnych grup społecznych.

W niniejszym artykule zaprezentujemy jedną z wielu możliwości realizacji zajęć z zakresu edukacji międzykulturowej w przedszkolach i szkołach podstawowych przy wykorzystaniu specjalnie opracowanych bajek międzykulturowych, które stanowią integralną część Programu Kształtowania Wrażliwości na Odmienność „Przygody Innego”. Scharakteryzujemy również istotę powstania programu i przebieg jego pilotażu oraz wybrane wnioski wynikające $\mathrm{z}$ ewaluacji inicjatywy.

\section{W stronę edukacji międzykulturowej w przedszkolu i szkole podstawowej}

Złożoność problematyki edukacji międzykulturowej i potrzebę jej rozpoczynania już we wczesnym dzieciństwie potwierdzają zarówno wnioski z badań naukowych, jak i codzienne doświadczenia nauczycieli pracujących w przedszkolach i szkołach. Z analizy wyników badań naukowych można wnioskować, że bez realizacji działań traktujących o równości wszystkich ludzi oraz kształtowania pozytywnego stosunku do Innego/Obcego postrzeganie odmienności może mieć negatywny kształt. Badania empiryczne wskazują, że już trzylatki mają uproszczony i nasycony negatywnym wartościowaniem obraz ludzi starszych $^{1}$. Natomiast dzieci w wieku od 7 do 13 lat przejawiają stereotypy i uprzedzenia dotyczące różnych grup społecznych (wiekowych, etnicznych,

1 Zob. wnioski z badań: D. Davidson, P. Cameron, D. Jergovic, cyt. za: B. Weigl: Stereotypy i uprzedzenia etniczne u dzieci i mtodzieży. Studium empiryczne. Warszawa 1999, IP PAN; E. Chromiec: Dziecko wobec obcości kulturowej. Gdańsk 2004, GWP, s. 31. 
językowych itp.) $)^{2}$. Przedszkolaki, choć charakteryzują się egocentrycznym podejściem do świata, już zaczynają interesować się dalszymi jego aspektami. Zdaniem Lwa S. Wygotskiego ważne jest, by prowadzić dziecko do przekraczania najbliższego kręgu jego rzeczywistości, pomagając w odkrywaniu nowych, nieznanych jeszcze dla niego obszarów. Stymuluje to rozwój procesów poznaw$\mathrm{czych}^{3}$. Wiek od 4 do 7 roku życia to także czas kształtowania się umiejętności dostrzegania odmienności innych ras i grup etnicznych ${ }^{4}$, a więc dobry moment do wprowadzania tematyki z tego zakresu do programów edukacyjnych. Warto podkreślić, że najmłodsze dzieci przenoszą stereotypowe patrzenie na to, co odmienne, a także uprzedzenia od osób dla nich ważnych - rodziców, dziadków, nauczycieli itp. Wrażliwość na odmienność, tolerancja i akceptacja Obcych/Innych jest wynikiem wychowania w domu oraz edukacji szkolnej. Istotną rolę w tym procesie odgrywają również środki masowego przekazu. Wczesne, stopniowe i adekwatne do możliwości percepcyjnych dziecka przybliżanie kwestii związanych z odmiennością tworzy bowiem ważny poznawczo fundament do współdziałania z Innymi/Obcymi.

Wystarczy obserwacja szkolnego czy przedszkolnego korytarza, aby dostrzec szereg różnic pomiędzy dziećmi. Ich podłożem są cechy biologiczne, kulturowe czy też te związane z sytuacją ekonomiczną. Cechy te dotyczą wymiarów ludzkiego funkcjonowania (biologicznego, kulturowego, ekonomicznego itd. $)^{5}$. Już podczas pierwszego kontaktu dostrzegamy odmienność związaną z cechami fizycznymi, np. ubiorem, kolorem skóry, oczu czy włosów. Obok różnorodności w wymiarze biologicznym czy ekonomicznym w placówkach edukacyjnych coraz bardziej widoczne są różnice w wymiarze kulturowym. Różnice te budzą w dzieciach różne emocje, od pozytywnych po negatywne. Rodzi się pytanie, jak przygotować wychowanków do funkcjonowania w coraz bardziej różnorodnym świecie?

2 Zob. wnioski z badań: K. K. Powlishta, L. A. Serbin, A. Doyle, D. R. White, cyt. za: B. Weigl: Stereotypy i uprzedzenia u dzieci i młodzieży. Studium empiryczne. cyt. wyd., s. 31.

3 Szerzej na ten temat L. S. Wygotski: Wybrane prace psychologiczne. Warszawa 1971, PWN.

4 P. Bryant, A. M. Dolman (red.): Psychologia rozwojowa. Poznań 1997, Zysk i S-ka, s. 82 .

5 Zob. Koncepcja postrzegania Innego i interakcji z Nim. W: J. Nikitorowicz: Kreowanie tożsamości dziecka. Wyzwania edukacji międzykulturowej. Gdańsk 2005, GWP, s. 105 i n. Zob. również: P. P. Grzybowski: Edukacja międzykulturowa - przewodnik. Pojęcia - literatura - adresy. Kraków 2008, Oficyna Wydawnicza „Impuls”, s. 10. 
Zadania współczesnej oświaty jasno określają zapisy w podstawie programowej wychowania przedszkolnego oraz kształcenia ogólnego w poszczególnych typach szkół ${ }^{6}$. Znajdujemy tam informacje, że już na poziomie najniższego etapu nauczania działania edukacyjne podjęte przez nauczycieli mają kształtować wśród wychowanków postawy poszanowania tradycji i kultury własnego narodu, a także poszanowania dla innych kultur i tradycji, postawy tolerancji, akceptacji prawa każdego człowieka do bycia innym. Aby dziecko zrozumiało otaczający nas świat różnorodności, nauczyciel nie może uciekać przed podejmowaniem działań w celu zapobiegania wszelkiej dyskryminacji. Praktyka pokazuje jednak, że zagadnienia edukacji międzykulturowej, pomimo obecności w podstawie programowej, traktowane są w sposób drugorzędny. Sprowadza się je do przekazywania wychowankom wiedzy na temat innych kultur, zwyczajów, religii. Za rzadko zwraca się uwagę dzieci na podobieństwa i różnice istniejące pomiędzy ludźmi. Bardzo często podczas inicjatyw realizowanych w placówkach oświatowych odmienność ukazywana jest w sposób powierzchowny i stereotypowy. Wciąż brakuje cyklicznych działań (programów i projektów) opierających się na solidnych podstawach merytorycznych, które poza przekazywaniem wiedzy zakładają kształtowanie pozytywnego stosunku emocjonalnego wobec Obcego/Innego oraz kształcenie umiejętności umożliwiających nawiązywanie partnerskich interakcji z Obcym/Innym. Inicjatyw, które ukazywać będą odmienność w atrakcyjny, rozwijający ciekawość poznawczą sposób oraz uwzględniać kwestie trudne - wiążące się z problemami i postawami wobec Obcych/Innych. Do jakich dziecięcych postaw to prowadzi?

Przerwa w niedużej szkole podstawowej w mieście wojewódzkim. Bezstronny obserwator szkolnego korytarza szybko dostrzeże różnorodność wyglądu, postaw, zachowań dzieci. Bardziej wnikliwy spróbuje wsłuchać się w dialogi dzieci. To, co usłyszy, może okazać się dla niego szokujące. Ale

6 Podstawa programowa wychowania przedszkolnego oraz kształcenia ogólnego w poszczególnych typach szkół z dnia 23 grudnia 2008 roku, opublikowana w dniu 15 stycznia 2009 roku w Dzienniku Ustaw Nr 4, poz. 17: W procesie ksztatcenia ogólnego szkoła podstawowa kształtuje u uczniów postawy sprzyjajace ich dalszemu rozwojowi indywidualnemu i społecznemu, takie jak: uczciwość, wiarygodność, odpowiedzialność, poczucie własnej wartości, szacunek dla innych ludzi, ciekawość poznawcza, kreatywność [...] , gotowość do uczestnictwa w kulturze. W rozwoju społecznym bardzo ważne jest kształtowanie postawy obywatelskiej, postawy poszanowania tradycji i kultury własnego narodu, a także postawy poszanowania dla innych kultur i tradycji. Szkoła podejmuje odpowiednie kroki w celu zapobiegania wszelkiej dyskryminacji. 
z ciebie wieśniak, ty grubasie, z okularnikami nie gadamy i dalej ty ciemniaku, schowaj się, twoja komórka jest sto lat za Murzynami... Przerażający scenariusz filmu czy szkolna rzeczywistość, tak okrutna dla wielu uczniów? Dlaczego dzieci bez bliższego poznania drugiej osoby, tak szybko wydają opinię na jej temat, wykorzystując stereotypowe poglądy, używając języka dyskryminacji? Doświadczana przez nie odmienność zamiast inspirować, ubogacać, staje się źródłem niechęci, lęków, konfliktów, poczucia zagrożenia, wzbudza agresywne zachowania, chęć dominacji. Podobne sytuacje można zaobserwować w wielu placówkach oświatowych. Przesądza to o konieczności realizacji programów edukacyjnych mających na celu coś więcej niż tylko uczenie o innych kulturach, języku, religii, tradycjach, ale przede wszystkim kształtujących pełne postawy otwartości i szacunku wobec inności w zakresach: biologicznym, ekonomicznym, społecznym, kulturowym, przy jednoczesnej akceptacji własnej tożsamości i dziedzictwa kulturowego.

Niepodejmowanie działań mających na celu przygotowanie do międzykulturowego dialogu może prowadzić do utwierdzania się stereotypów i uprzedzeń, które w konsekwencji mogą przerodzić się w zachowania dyskryminujące.

\section{Istota bajek międzykulturowych}

Bajki międzykulturowe powstały na potrzeby realizacji Programu Kształtowania Wrażliwości na Odmienność „Przygody Innego”, który stanowi przykład inicjatywy skierowanej do dzieci w wieku przedszkolnym i wczesnoszkolnym. Program powstał dzięki zaangażowaniu dwóch organizacji pozarządowych: Fundacji Uniwersytetu w Białymstoku oraz Fundacji Edukacji i Twórczości w Białymstoku ${ }^{7}$. Czynnikami decydującymi o jego opracowaniu i wdrożeniu były doświadczenia wynikające z kilkuletniej współpracy z podlaskimi przedszkolami i szkołami ${ }^{8}$ oraz rozmowy z władzami miasta Białegostoku zaniepokojonymi aktami przemocy i wandalizmu na tle rasistowskim. Głównym

7 Autorkami idei programu są: Anna Młynarczuk-Sokołowska (Fundacja Uniwersytetu w Białymstoku) i Katarzyna Potoniec (Fundacja Edukacji i Twórczości). Koncepcyjnie i merytorycznie program opracowała A. Młynarczuk-Sokołowska.

8 Współpraca dotyczyła realizacji inicjatyw edukacyjnych, m.in. takich jak: projekt edukacyjny Ku wzbogacającej różnorodności (więcej zob. roznorodnosc.uwb. edu.pl), konkurs Różnorodność przestrzeniq dialogu (http://fundacja.uwb.edu.pl/), angażujących dzieci polskie, czeczeńskie oraz przynależące do mniejszości etnicznych i narodowych. 
celem i zadaniem programu jest kształtowanie wrażliwości na odmienność, która umożliwia radzenie sobie w interakcjach z Obcymi/Innymi różniącymi się od dziecka w wielu zakresach (biologicznym, ekonomicznym, społecznym, kulturowym) oraz nawiązywanie z nimi partnerskich relacji ${ }^{9}$. U podstaw tych interakcji leżą: świadomość prawa każdego człowieka do bycia Innym, emocjonalna gotowość do wchodzenia w interpersonalne kontakty z Obcy$\mathrm{mi} /$ Innymi, a także umiejętność respektowania zasad równego traktowania wszystkich ludzi. Ze względu na dynamiczne kulturowe różnicowanie się społeczeństwa polskiego oraz specyfikę wielokulturowego Podlasia, szczególny akcent został położny na odmienność w zakresie kulturowym. Treści zawarte w programie dotyczą różnych kategorii ludzi, problemów oraz kultury Obcego/Innego bliskiego i dalekiego. Zaletą takiego postępowania jest ukierunkowanie na polepszenie stosunku do ludzi w ogóle, a nie do określonej grupy ludzi ${ }^{10}$. Program oparty jest na koncepcjach naukowych i wnioskach $\mathrm{z}$ badań empirycznych ${ }^{11}$. Przeznaczony jest do realizacji w przedszkolach i szkołach podstawowych wśród dzieci w wieku od 5 do 9 lat (w tej grupie wiekowej został przeprowadzony jego pilotaż), jak i innych instytucjach podejmujących działania o charakterze edukacyjnym. Program można realizować także w młodszych, jak i starszych grupach, modyfikując jego treści oraz dostosowując czas trwania zajęć do możliwości percepcyjnych dzieci.

Podstawą realizacji programu Przygody Innego są autorskie bajki międzykulturowe opracowane przez nauczycieli i edukatorów zaangażowanych w realizację edukacji międzykulturowej. Bajki międzykulturowe wpisują się w kanon bajek psychoedukacyjnych i zarazem w nurt biblioterapii wychowawczej

9 Zob. A. Młynarczuk-Sokołowska: Program Kształtowania Wrażliwości na Odmiennośc „Przygody Innego”. W: A. Młynarczuk-Sokołowska, K. Potoniec, K. Szostak-Król (red.): Przygody Innego. Białystok 2011, Fundacja Edukacji i Twórczości, Fundacja Uniwersytetu w Białymstoku, s. 21-26.

10 Szerzej na ten temat zob. wskazówki dotyczące konstruowania programów edukacyjnych: B. Weigl: Stereotypy i uprzedzenia etniczne u dzieci i mtodzieży - istota zjawiska i przesłanki zmian. W: K. Białek, T. Halik, A. Marek, R. Szuchta, B. Weigl (red.): Edukacja przeciw dyskryminacji. Warszawa 2008, Stowarzyszenie Vox Humana, s. 104-105.

11 Teoretyczny fundament programu stanowią: Koncepcja postrzegania Innego i interakcji z Nim (J. Nikitorowicz), Koncepcje góry lodowej w kontekście poznawania odmiennej tożsamości i kultury, wnioski z badań na temat kształtowania się stereotypów i uprzedzeń wśród dzieci (D. Davidson, P. Cameron, K. K. Powlishta itd.) oraz koncepcje dotyczące rozwoju dziecka (J. Piaget, L. S. Wygotski, E. H. Erikson itd.). 
(rozwojowej). Bajka międzykulturowa jest utworem skierowanym do dzieci, którego zadaniem jest uwrażliwianie ich na istniejące różnice pomiędzy ludźmi we wszystkich zakresach funkcjonowania człowieka: biologicznym, ekonomicznym, społecznym i kulturowym, które są permanentnie wpisane w każdą rzeczywistość społeczną ${ }^{12}$. Treści zawarte w bajkach międzykulturowych pozwalają dzieciom poznać przede wszystkim problemy osób funkcjonujących w roli Obcego/Innego oraz zrozumieć prawo każdego człowieka do bycia innym. Umożliwiają również dostrzeżenie różnorodności świata, rozwijanie ciekawości poznawczej i chęć wchodzenia w interakcje z Obcym/Innym. Na użytek programu powstały bajki podejmujące problematykę: odmienności biologicznej Leśne przygody Innego (Agnieszka Sołbut), sprawności i niepełnosprawności fizycznej Inny i strach przed ciemnościq (Jolanta Stanisławska), odmienności ekonomicznej Inny i poszukiwanie skarbów (Katarzyna Szostak-Król), różnic religijnych i wyznaniowych Spotkanie Innego ze Strażnikiem Myśli (Małgorzata Rusiłowicz), odmienności etnicznej Wizyta Innego w cygańskim taborze (Małgorzata Rusiłowicz), a także sytuacji uchodźców Inny na uchodźczym szlaku (Katarzyna Szostak-Król) oraz kulturowej odmienności imigranta - Innego/Obcego dalekiego, Podróż Innego do Krainy Smoka (Ewelina Rusicka-Karoui). Dzięki wykorzystaniu dydaktycznej mocy bajek można rozmawiać z najmłodszymi w sposób dla nich zrozumiały i atrakcyjny o ważnych problemach. Zaproponowane bajki ${ }^{13}$ nie wyczerpują jednak problematyki zjawiska odmienności - stanowią propozycje metodyczne przydatne w pracy z dziećmi. Tworzenie bajek międzykulturowych może stać się twórczym zajęciem dla nauczycieli oraz wszystkich zainteresowanych uwrażliwianiem na odmienność najmłodszych. Program ma na tyle otwartą formułę, że każdy nauczyciel, pedagog, rodzic (po uprzednim przygotowaniu się) może stworzyć własną bajkę międzykulturową $\mathrm{w}$ odpowiedzi na zdiagnozowany $\mathrm{w}$ grupie problem $\mathrm{w}$ dowolnym obszarze odmienności. Rolę eksperta (czasami też głównego bohatera) pełni w bajkach Inny. Słucha on zwierzeń bohaterów, doświadcza różnych trudnych sytuacji związanych z odmiennością, pokazuje konkretne sposoby

12 Definicja bajki międzykulturowej została opracowana na potrzeby programu Przygody Innego. Szerzej na ten temat zob.: K. Potoniec: Bajki w edukacji międzykulturowej. W: A. Młynarczuk-Sokołowska, K. Potoniec, K. Szostak-Król (red.): Przygody Innego. cyt. wyd., s. 12-13.

13 Treść bajek oraz scenariusze zajęć do pracy z bajką, a także scenariusze zajęć wprowadzających i podsumowujących można znaleźć w: A. Młynarczuk-Sokołowska, K. Potoniec, K. Szostak-Król (red.): Przygody Innego. cyt. wyd. 
rozwiązań sytuacji konfliktowych. Jest także autorytetem, który ukazuje małym odbiorcom bajek pozytywne aspekty różnorodności świata.

Bajki międzykulturowe pełnią funkcję wprowadzenia do rozmowy z dziećmi na temat odmienności, ale realizacja zajęć dydaktycznych przy wykorzystaniu metody pracy z bajką międzykulturową nie ogranicza się do przekazu treści w nich zawartych. Zakłada ona wykorzystanie całego wachlarza metod dydaktycznych (waloryzacyjne, praktyczne, samodzielnego dochodzenia do wiedzy, asymilacji wiedzy), które angażują wszystkie sfery aktywności dziecka oraz stanowią urozmaicenie i wzbogacenie pracy podczas zajęć. Praca za pomocą bajek międzykulturowych przebiega według następującego schematu: zajęcia prowadzone przy wykorzystaniu bajki międzykulturowej, wzbogacane aktywizującymi metodami oraz następujące po nich zajęcia wzmacniające, których celem jest utrwalenie wiedzy z poprzedniego spotkania oraz poszerzenie jej o nowe, pokrewne treści. Omawiany model pracy stwarza dziecku przestrzeń do kontaktów z Obcymi/Innymi, poprzez pogłębianie przemyśleń, przewartościowanie sposobu postrzegania odmienności oraz służy pracy nad zachowaniami. Przyczynia się również do kształtowania tożsamości dziecka, rozwijając poczucie własnej przynależności do określonej grupy (narodowościowej, etnicznej, religijnej) i wartości przez nią reprezentowanych. Założeniem pracy z wykorzystaniem bajek międzykulturowych jest rozwijanie wrażliwości na odmienność poprzez oddziaływanie na: intelekt, emocje, zachowania, kształtowanie umiejętności społecznych i kompetencji międzykulturowej. Zakłada ona uczenie się zachowań opartych o zaciekawienie, zasady tolerancji, akceptacji i szacunku wobec osób różniących się od dziecka. Stwarza okazję do ekspresji werbalnej, plastycznej i ruchowej, zachęca uczestników do aktywnego udziału w zajęciach, do samodzielnego myślenia, czerpania z własnej wiedzy, obserwacji i doświadczeń. W grupach dzieci młodszych warto położyć akcent na ekspresję plastyczną, zaś dzieciom starszym stwarzać więcej okazji do wypowiadania własnego zdania ${ }^{14}$. W przypadku dzieci młodszych ważne jest także, by często przerywać czytanie bajki zadaniami i pytaniami. Dzieci mogą mieć problem z koncentracją uwagi na słuchaniu bajki przez dłuższy czas. Warto też prowadzić wspólnie zajęcia z osobą wspomagającą nauczyciela. Samodzielne prowadzenie zajęć może utrudniać jednoczesne czytanie bajek i animowanie ruchów pacynki. W trakcie

14 Dzieci robią to chętnie, gdy mają taką możliwość - wskazują na to m.in. doświadczenia wynikające z realizacji pilotażu programu oraz obserwacje własne. 
realizacji programu ważną rolę odgrywają również spotkania dodatkowe z Obcymi/Innymi, których płaszczyzną jest bezpośrednia interakcja. Oprócz metodycznie zaplanowanego uczenia się, dają one możność zadawania pytań, oswojenia się z innym językiem i obecnością osób przynależących do odmiennych kultur, jak i również przełamania lęku i wykroczenia poza negatywne stereotypy i uprzedzenia. Program zakłada wykorzystanie indywidualnej, zbiorowej i grupowej formy pracy, ze szczególnym uwzględnieniem tej ostatniej, która rozwija umiejętność dzielenia się doświadczeniami i współdziałania. Realizacja programu powinna zostać poprzedzona zajęciami wprowadzającymi, które oprócz przybliżenia uczestnikom omawianych zagadnień i integracji grupy, mają na celu wstępną diagnozę (za pomocą rysunku i pogadanki) wizerunku Obcego/Innego oraz postaw wobec niego. Program kończą zajęcia podsumowujące, które pozwalają na podsumowanie nabytej wiedzy i umiejętności oraz określenie za pomocą tych samych technik zmian w postrzeganiu Obcego/Innego.

Zaprezentowana powyżej metoda pracy z wykorzystaniem bajek międzykulturowych stanowi propozycję nowego rozwiązania metodycznego w obszarze edukacji międzykulturowej dzieci w wieku przedszkolnym i wczesnoszkolnym oraz daje podstawę do projektowania całego wachlarza twórczych działań wszystkim zainteresowanym edukacją najmłodszych.

\section{Słów kilka na temat pilotażu Programu Kształtowania Wrażliwości na Odmienność „Przygody Innego”}

W roku akademickim 2010/2011 studenci - wolontariusze z Fundacji Uniwersytetu w Białymstoku oraz nauczyciele zrealizowali w siedmiu podlaskich placówkach (przedszkolach, oddziałach zerowych i klasach I- II) ${ }^{15}$ pilotaż Programu Kształtowania Wrażliwości na Odmienność „Przygody Innego”. Wzięło w nim udział dwustu dwudziestu jeden uczniów. Grupy, w których inicjatywa została zrealizowana, były bardzo różnorodne. Poza różnicami w zakresie interpersonalnym, wśród uczestników obecne były także odmienności w wymiarze biologicznym, narodowościowym, wyznaniowym i religijnym. W programie uczestniczyły trzy klasy, do których uczęszczają dzieci

15 Za merytoryczne przygotowanie wolontariuszy, korektę bajek międzykulturowych i scenariuszy zajęć oraz koordynowanie przebiegu pilotażu programu w przedszkolach i szkołach (październik 2010-luty 2011) odpowiadały A. Młynarczuk-Sokołowska i K. Szostak-Król. 
czeczeńskie, klasa, w której istnieje znaczące zróżnicowanie pod względem wyznaniowym i religijnym (prawosławni, protestanci, świadkowie Jehowy), grupa sześciolatków z przedszkola integracyjnego (w tym kilkoro dzieci z zespołem Downa, opóźnieniem intelektualnym i autyzmem) itd.

Pilotażowa wersja programu realizowana była w bezpiecznej, przyjaznej atmosferze, w aktywny sposób. Zajęcia prowadzone w oparciu o bajki międzykulturowe i zajęcia wzmacniające umożliwiały dzieciom dzielenie się własnymi spostrzeżeniami oraz włączanie elementów własnej kultury do procesu uczenia się. Poza tym w ramach realizacji pilotażu inicjatywy odbyły się pozalekcyjne spotkania z Obcymi/Innymi, dotyczące ich kultury (wizyta czeczeńskiego zespołu Lowzar i wolontariuszki z Niemiec), które dawały szansę rzeczywistego spotkania z osobami przynależącymi do odmiennych grup narodowych. Spotkania te pozwoliły na wykroczenie poza negatywne stereotypy i uprzedzenia oraz kształtowanie pozytywnego stosunku wobec Obcego/Innego na drodze bezpośrednich interakcji. Zajęcia pozalekcyjne stwarzały również przestrzeń dla aktywnego uczestnictwa rodziców. Metody pracy stosowane $\mathrm{w}$ trakcie realizacji programu umożliwiały swobodne, twórcze działanie, skłaniały do myślenia. Dzieci z przyjemnością uczestniczyły w zajęciach. Nieoceniony wpływ miała na to właśnie pacynka Inny, z którą dzieci bardzo szybko związały się emocjonalnie. Z zaangażowaniem słuchały bajek, brały udział w grach i zabawach dydaktycznych, wykonywały prace plastyczne, zadania ruchowe oraz wypowiadały swoje opinie na tematy podejmowane podczas zajęć ${ }^{16}$.

Ewaluacja pilotażu programu wskazywała na jego powodzenie i efektywnośćc ${ }^{17}$. Wypowiedzi dzieci, jak i wykonane przez nie rysunki świadczyły o znacznym poszerzeniu perspektywy postrzegania odmienności i świado-

16 Świadczą o tym wypowiedzi dzieci, jak i opinie realizujących pilotaż programu wolontariuszy i nauczycieli.

17 Punktem odniesienia do niniejszych wniosków były rozmowy z dziećmi przeprowadzone podczas pierwszych zajęć, ich uzupełnienie stanowiły natomiast wykonane przez nie rysunki pt. Inny. Wypowiedzi dzieci zgromadzone podczas pierwszych zajęć świadczyły głównie o postrzeganiu Obcego/Innego jako osoby z wyimaginowanej galaktyki (tzw. kosmita), odległych kontynentów i krajów (głównie: Afrykańczyk, Chińczyk, Indianin, różniących się kolorem skóry i ubiorem), rzadziej jako osób innego wzrostu, w różnym wieku czy o niższym statusie ekonomicznym. Szerzej na temat ewaluacji pilotażu Programu Kształtowania Wrażliwości na odmienność „Przygody Innego”. Zob.: Inny w bajkach $i$ wśród nas, czyli o uczestnictwie w międzykulturowej edukacji nieformalnej. W: Przygody Innego. Bajki w edukacji międzykulturowej. cyt. wyd., s. 14-17. 
mości problemów z nią związanych. Dzieci zaczęły dostrzegać np. problemy osób z otyłością, niewidomych oraz uchodźców, których przed rozpoczęciem pilotażu programu w wielu grupach nie dostrzegały. Zaobserwowano również większą gotowość i chęć do nawiązywania relacji koleżeńskich i przyjacielskich z Obcymi/Innymi. W wypowiedziach dzieci pojawiały się komunikaty, świadczące o zrozumieniu istoty szacunku i równego traktowania wszystkich ludzi bez względu na różnice oraz chęć wchodzenia w partnerskie relacje z Obcymi/Innymi, potrzeba ich tolerancji, akceptacji i wspierania. Poniżej prezentujemy wybrane refleksje uczestników pilotażu programu na temat nabytej wiedzy i umiejętności.

Ja się nauczyłam tego, że nieważne jest, czy ktoś ma ładne ubranie, czy tadnie wyglada, czy ma wade wymowy, to i tak trzeba go zaakceptować, bo jak go poznamy bliżej, to może się okazać, że on jest naprawde w czymś dobry. Nauczytam się jeszcze, że nie trzeba go obgadywać, że ktoś jest $z$ innego kraju i że oni sq dziwni. Agata.

Nauczytem się tego, że trzeba szanować inne osoby, nie można się od nich odwracać. Trzeba je szanować, tak jak osoby takie jak my. Trzeba wszystkich szanować $i$ się z nimi przyjaźnić. Ja myślę, że to będzie dla mnie bardzo przydatne, bo tam się nauczyliśmy kultury do innych ludzi $i \dot{z} e$ trzeba wszystkich lubić, nie można kogoś nie lubić tylko dlatego, że jest Inny. Adrian.

Nauczytam się np. tego, że jak ktoś jest Inny - nie możemy wyśmiewać się z Innych, bo ktoś ma np. ciemna skórę. Jak będę widziata inna osobę, innej narodowości to będę wiedziata, że nie mogę się z niej wyśmiewać. Faustyna.

\section{Zakończenie}

Współcześnie coraz częściej teoretycy i praktycy zajmujący się edukacją podkreślają potrzebę realizacji idei edukacji międzykulturowej już od najwcześniejszych etapów kształcenia. Przemawiają za tym potrzeby społeczne wynikające z kształtu współczesnej, polskiej rzeczywistości społeczno-kulturowej, której obserwacje pokazują, że różnice pomiędzy ludźmi stają się coraz bardziej widoczne. Program Kształtowania Wrażliwości na Odmienność „Przygody Innego", którego podstawą realizacji są bajki międzykulturowe jest metodyczną propozycją cyklu zajęć, które można przeprowadzić w przedszkolach i szkołach 
oraz innych placówkach prowadzących działalność edukacyjną. Powstał jako próba odpowiedzi na potrzeby wynikające $\mathrm{z}$ funkcjonowania w szczególnym, zróżnicowanym kulturowo regionie, jakim jest Podlasie. Obecnie program realizowany jest na terenie kilkunastu polskich placówek (na Podlasiu, w Warszawie i Poznaniu). Inicjatywa została doceniona na poziomie wojewódzkim (I miejsce w konkursie Wojewody Podlaskiego Inicjatywa Społeczna roku 2010) oraz międzynarodowym (I miejsce w konkursie Światowej Organizacji Wychowania Przedszkolnego OMEP). Efektem twardym przedsięwzięcia jest recenzowana, rekomendowana przez Podlaskiego Kuratora Oświaty publikacja metodyczna pt. Przygody Innego. Bajki w edukacji międzykulturowej, która zawiera między innymi bajki międzykulturowe oraz scenariusze zajęć do pracy w przedszkolach i szkołach podstawowych ${ }^{18}$.

\section{Bibliografia}

Białek K., Halik T, Marek A., Szuchta R., Weigl B. (red.): Edukacja przeciw dyskryminacji. Warszawa 2008, Stowarzyszenie Vox Humana.

Chromiec E.: Dziecko wobec obcości kulturowej. Gdańsk 2004, GWP.

Grzybowski P. P.: Edukacja międzykulturowa - przewodnik. Pojęcia - literatura - adresy. Kraków 2008, Oficyna Wydawnicza „Impuls”.

Młynarczuk-Sokołowska A.: Inny w bajkach $i$ wśród nas, czyli o uczestnictwie $w$ międzykulturowej edukacji nieformalnej. W: A. Młynarczuk-Sokołowska, K. Potoniec, K. Szostak-Król (red.): Przygody Innego. Bajki w edukacji międzykulturowej. Białystok 2011, Fundacja Edukacji i Twórczości, Fundacja Uniwersytetu w Białymstoku.

Młynarczuk-Sokołowska A.: Program Kształtowania Wrażliwości na Odmienność „Przygody Innego”. W: A. Młynarczuk-Sokołowska, K. Potoniec, K. Szostak-Król (red.): Przygody Innego. Bajki w edukacji międzykulturowej, Białystok 2011, Fundacja Edukacji i Twórczości, Fundacja Uniwersytetu w Białymstoku.

Podstawa programowa wychowania przedszkolnego oraz kształcenia ogólnego w poszczególnych typach szkół z dnia 23 grudnia 2008 roku. Dziennik Ustaw z dnia 15 stycznia 2009 roku, nr 4, poz. 17.

18 Osoby zainteresowane otrzymaniem nieodpłatnej publikacji mogą otrzymać ją pocztą. Zamówienia należy składać na adres e-mailowy: biuro@mentoring.org.pl. 
Potoniec K.: Bajki w edukacji międzykulturowej. W: A. Młynarczuk-Sokołowska, K. Potoniec, K. Szostak-Król (red.): Przygody Innego. Bajki w edukacji międzykulturowej. Białystok 2011, Fundacja Edukacji i Twórczości, Fundacja Uniwersytetu w Białymstoku.

Weigl B.: Stereotypy i uprzedzenia etniczne u dzieci i młodzieży. Studium empiryczne. Warszawa 1999, IP PAN.

\section{Intercultural fairy tales - in search for methodical solutions in the field of intercultural education of pre- and early-school children}

\section{Summary}

The article characterizes possibility of realization intercultural education with kindergarten and younger school children by multicultural stories on the example of Programme for the Development of Sensitivity to Otherness "Adventures of Different". The foundations of the programme are a series of lessons according to the following order: the lessons where interculticultural stories are used and enriched with the active teaching methods, the consolidating lessons afterwards with the aim to consolidate the knowledge from the previous lessons and to expand it by new, related elements. The interculticultural stories go within the canon of psycho-educative stories as well as with the trend of educative bibliotherapy (developmental). Working with the discussed stories enables the development of sensitivity to otherness in different aspects (biological, economic, social and cultural). It enables the target students to get closer with the diversity of the world, to give it the value and to develop the cognitive curiosity and the willingness to interact with the Aliens/Different. The interculticultural stories create the space for preparation of a child to contacts with the Aliens/Different by deepening the afterthoughts of the readers, revaluation of the way of seeing the difference and are useful for work on the behaviour. They also influence the process of development of a child's identity by explaining his own belonging to a specific group (national, ethnic, religious) and the values represented by it. Anna Młynarczuk-Sokołowska, Katrzyna Szostak-Król. 